ISSN 0103-5150

Fisioter. Mov., Curitiba, v. 30, n. 3, p. 501-507, Jul./Sep. 2017

Licenciado sob uma Licença Creative Commons

DOI: http://dx.doi.org/10.1590/1980-5918.030.003.A008

(c)

\title{
Handgrip and functional capacity in Chronic Obstructive Pulmonary Disease patients
}

\author{
Força de preensão palmar e capacidade funcional em \\ portadores de Doença Pulmonar Obstrutiva Crônica
}

\begin{abstract}
Andrea Lúcia Gonçalves da Silva ${ }^{[a, b]}$, Eduardo Garmatz ${ }^{[b]}$, Cássia da Luz Goulart ${ }^{[a]}$, Lisiane Lisboa Carvalho ${ }^{[a, b]}$, Dannuey Machado Cardoso ${ }^{[a, c]}$, Dulciane Nunes Paiva ${ }^{[a]}$
\end{abstract}

[a] Universidade de Santa Cruz do Sul (UNISC), Santa Cruz do Sul, RS, Brazil

[b] Hospital Santa Cruz, Santa Cruz do Sul , RS, Brasil

[c] Universidade Federal do Rio Grande do Sul, Porto Alegre, RS, Brazil

\begin{abstract}
Introduction: In the Chronic Obstructive Pulmonary Disease (COPD) both pulmonary and systemic condition increase dyspnea, intolerance to exercise and inactivity. Objective: To evaluate possible association between Hand Grip Strength (HGS) and the distance covered in the Six-Minute Walk Test (6MWT) in patients with Chronic Obstructive Pulmonary Disease (COPD). Methods: A cross-sectional study that evaluated 34 patients with COPD from moderate to very severe stages. The HGS test was performed with a manual hydraulic dynamometer (Jamar ${ }^{\circledR}$, California, USA) with three bilateral measures, allowing
\end{abstract}

\footnotetext{
ALGS: PhD, e-mail: andreag@unisc.br EG: BS, e-mail: eduardogarmatz@unisc.br CLG: undergrad, e-mail: luz.cassia@hotmail.com

LLC: MS, e-mail: lisianecarvalho@unisc.br

DMC: Doctoral Student, e-mail: dannueyc@unisc.br

DNP: PhD, e-mail: dulciane@unisc.br
} 
60-seconds rest time in-between measurements. Afterwards, the patients were submitted to the 6MWT along a 30-meters level corridor following the rules of the American Thoracic Society. Results: Average age $62.7 \pm 7.2$ years old, body mass index $26.7 \pm 6.9 \mathrm{Kg} / \mathrm{m}^{2}$. The value of the HGS in the dominant hand was 28.0 $\pm 8.7 \mathrm{Kgf}$ and in the non-dominant hand was $26.7 \pm 7.7 \mathrm{Kgf}(99.2 \%$ of the predicted value and $106.3 \%$ of the predicted value, respectively). The subjects covered in average $421.0 \pm 110.4$ meters in the 6MWT and there has been detected direct and significant correlation between the distance covered and the HGS of the dominant hand $(r=0,430 ; p=0,011)$ and non-dominant $(r=0,502 ; p=0,002)$. The patients with COPD that presented lower HGS also covered less distance in the 6MWT. Conclusion: The hand grip strength was directly associated with the functional capacity assessed through the distance covered in the SixMinute Walk Test in the evaluated trial.

Keywords: Hand Strength. Exercise Test. Pulmonary Disease. Chronic Obstructive.

\section{Resumo}

Introdução: Nos portadores de Doença Pulmonar Obstrutiva Crônica (DPOC), a disfunção pulmonar, as manifestações sistêmicas e o aumento da dispneia podem conduzir à piora progressiva do condicionamento físico, à inatividade e intolerância ao exercício físico. Objetivo: avaliar possível associação entre a força de preensão palmar (FPP) e a distância percorrida no Teste de Caminhada de Seis Minutos (TC6M) em portadores de DPOC. Métodos: Estudo transversal que avaliou 34 portadores de DPOC com estadiamento entre moderado a muito severo. A FPP foi realizada com dinamômetro hidráulico manual (Jamar ${ }^{\circledR}$, Califórnia, EUA) com três medidas bilateralmente, respeitando um tempo de descanso de 60 segundos entre as medidas. Posteriormente, os pacientes foram submetidos ao TC6M em um corredor plano de 30 metros, seguindo as normas da American

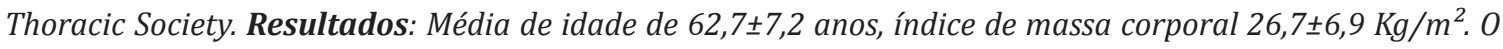
valor da FPP na mão dominante foi $28,0 \pm 8,7 \mathrm{Kgf}$ e da mão não dominante foi $26,7 \pm 7,7 \mathrm{Kgf}$ (99,2\% do predito e 106,3\% do predito, respectivamente). Os sujeitos percorreram em média 421,0 $\pm 110,4$ metros no TC6M tendo sido detectada correlação direta e significativa entre a distância percorrida e a FPP da mão dominante $(r=0,430 ; p=0,011)$ e não-dominante $(r=0,502 ; p=0,002)$. Os portadores de DPOC que apresentaram menor $F P P$ apresentaram menor distância no TC6M. Conclusão: A força de preensão palmar esteve diretamente associada à capacidade funcional avaliada através da distância percorrida no Teste de Caminhada de Seis Minutos na amostra avaliada.

Palavras-chave: Força da mão. Teste de Esforço. Doença Pulmonar. Obstrutiva Crônica.

\section{Introduction}

The Chronic Obstructive Pulmonary Disease (COPD) is characterized by persistent and progressive obstruction of the superior airways, associated with an enhanced chronic inflammatory response to inhalation of pollutants/particles or noxious gases (1). The inflammatory cells are active and there is an increase in pro-inflammatory plasma cytokine levels in the systemic circulation, causing oxidative stress that will result in musculoskeletal disorders and reduction of the functional capacity (2). The pulmonary dysfunction, the systemic manifestations and the increase of dyspnea can lead to progressive worsening of the physical conditioning, inactivity and physical exercise intolerance (3).

As a result, the COPD patient adopts a more sedentary lifestyle that worsens the quality of life and is the determining factor to the progression of the disease $(2,4)$. The evaluation of the physical performance of patients with COPD by using sub-maximal and non-invasive tests, like the Six-Minute Walk Test (6MWT), besides being easy to apply, can also reflect in activities of daily life, physical fitness, functional capacity (5), as well as monitor the effectiveness of several treatments due to its good correlation with 
the maximal oxygen uptake $\left(\mathrm{VO}_{2} \max \right)(6)$. Another important method to evaluate the changes of peripheral muscle strength, as this is one of the most important extra pulmonary manifestations of the COPD physiopathology (7), is the Hand Grip Strength (HGS). The HGS has as principle to estimate the musculoskeletal function through good reproducibility for the measurement of maximal manual voluntary handgrip strength, being considered a good index for overall muscle strength, and it can also reflect the impairment of the functional capacity (8).

We hypothesized that the reduction of hand grip strength is associated with the decrease of functional capacity in patients with COPD. Therefore, our objective was to evaluate the association between hand grip strength and the distance covered in the SixMinute Walk Test in patients with Chronic Obstructive Pulmonary Disease.

\section{Methods}

This descriptive, prospective and transversal study was carried out in the Pulmonary Rehabilitation Program at the Santa Cruz Hospital. It was approved by the Research Ethics Committee of the University of Santa Cruz do Sul (protocol number 435093/2013). The study population was composed of patients diagnosed with COPD in accordance with the international criteria (1).

There were forty-one COPD patients eligible in the program, however, only Thirty-four met the following inclusion criteria: age between 40 and 80 years old, with clinical diagnosis of COPD through the pulmonary function test by spirometry and clinically stable. COPD patients with musculoskeletal disorders, neurological sequelae that would affect the locomotor system and cognitive deficit, skin lesions on the feet and/or superior limbs, exacerbations of the disease within the 30 days prior to the study and the ones with lung cancer diagnosis, were excluded.

\section{Clinical Variables}

Analysis of the expiratory volume forced in the $1^{\circ}$ second $\left(\mathrm{FEV}_{1}\right)$, relation expiratory volume forced in the $1^{\mathrm{o}}$ second/vital capacity forced $\left(\mathrm{FEV}_{1} / \mathrm{VCF}\right)$, Socio-demographic and clinical data (gender, age, Body Mass Index - BMI, time of the diagnosis of the
COPD, smoking history, dyspnea by the scale Medical Research Council - MRC and index of BODE - Body Mass-Index: Airflow Obstruction, Dyspnea and Exercise Capacity).

\section{Handgrip Strength}

The HGS test was performed with a manual hydraulic dynamometer (Jamar ${ }^{\circledR}$, California, USA), following the recommendations of The American Society of Hands Therapists. The patients remained seated, with the shoulder abducted, elbow flexed at $90^{\circ}$, forearm in neutral position of prono-supination and the wrist joint between $0^{\circ}$ and $30^{\circ}$ of dorsiflexion. Three bilateral measures were taken, allowing 60 seconds rest time in-between measurements, and the average of the measurements of each participant was separately calculated. The values obtained compared with the ones predicted as reported by Luna-Heredia et al. (9).

\section{MWT}

The 6MWT was performed according to the American Thoracic Society standards to measure the distance the study participants were able to walk within a 6-minute period (10). The study participants were asked to walk as far as possible at a self-determined speed. No other guidance was provided. The test was carried out by an experienced physical therapist. The percentage predicted in the $6 \mathrm{MWT}$ distance was calculated considering gender, age, height, and weight of each subject based on the equation by Enright, et al. (11).

\section{Statistical analysis}

The software SPSS (version 20.0) was used to verify the normality of the distribution of data through the test of Shapiro-Wilk, and the results were shown in frequency, average \pm standard deviation. The association between the variables was analyzed by using Spearman's correlation test and the analysis of the variance for multiple comparisons (ANOVA) by using the post hoc of Tukey test. It was considered significant a $\mathrm{p}<0.05$. 


\section{Results}

The clinical characteristics and the performance of the 34 COPD patients in the tests are shown in Table 1.

Table 1 - Clinical Characteristics and performance in tests of patients with COPD

\begin{tabular}{|c|c|}
\hline Variables & COPD. $(n=34)$ \\
\hline Sex Male. n (\%) & $18(52,9)$ \\
\hline Age (years) & $62.7 \pm 7.2$ \\
\hline BMI. $\left(\mathrm{Kg} / \mathrm{m}^{2}\right)$ & $26.7 \pm 6.9$ \\
\hline \multicolumn{2}{|l|}{ Classification BMI } \\
\hline Underweight. n (\%) & $07(20.6)$ \\
\hline Normal weight. $\mathrm{n}(\%)$ & $11(32.4)$ \\
\hline Obesity. n (\%) & $16(47.1)$ \\
\hline \multicolumn{2}{|l|}{ Spirometrics } \\
\hline FEV $1 . \%$ predicted & $39.1 \pm 15.3$ \\
\hline $\mathrm{FEV}_{1} / \mathrm{FVC} . \%$ predicted & $62.3 \pm 19.2$ \\
\hline \multicolumn{2}{|l|}{ GOLD* } \\
\hline II. n (\%) & $7(21.2)$ \\
\hline III. n (\%) & $16(48.5)$ \\
\hline IV. n (\%) & $11(30.3)$ \\
\hline Smoking (years) & $36.0 \pm 9.6$ \\
\hline Former. n (\%) & $27(79.4)$ \\
\hline Current. n (\%) & $07(20.6)$ \\
\hline BODE index & $3.4 \pm 2.0$ \\
\hline Quartile I. n (\%) & $11(33.3)$ \\
\hline Quartile II. n (\%) & $15(45.5)$ \\
\hline Quartile III. n (\%) & $05(15.2)$ \\
\hline Quartile IV. n (\%) & $02(6.1)$ \\
\hline \multicolumn{2}{|l|}{ 6MWT } \\
\hline Distance (m) & $421.0 \pm 110.4$ \\
\hline Distance. (\% predicted) & $99.1 \pm 34.1$ \\
\hline \multicolumn{2}{|l|}{ Hand Grip } \\
\hline Dominant (Kgf) & $28.03 \pm 8.7$ \\
\hline Dominant (\% predicted) & $99.2 \pm 31.6$ \\
\hline Non-Dominant (Kgf) & $26.72 \pm 7.7$ \\
\hline Non-Dominant (\% predicted) & $106.3 \pm 37.5$ \\
\hline
\end{tabular}

Note: Data are presented as mean $\pm \mathrm{SD} ; n(\%)$ : number sample (frequency); COPD, chronic obstructive pulmonary disease; BMI, body mass index; Classification of BMI second Cuppari et al. (12); GOLD: Global Initiative for Chronic Lung Disease; FEV1, forced expiratory volume in 1 second; $F E V 1 / F V C=$ forced expiratory volume in the first second and forced vital capacity. \% predicted secund Pereira et al. (13) BODE index: Body Mass-Index. Airflow Obstruction. Dyspnea and Exercise Capacity; Quartile I: 0 to 2 points; Quartile II: 3 to 4 points; Quartile III: 5 to 6 points; Quartile IV: 7 to 10 points. 6MWT: 6-minute walk test. \% predicted secund Enright, et al. (11)
Direct correlations were observed between the measures of the HGS of the dominant hand and the non-dominant hand with the distance covered in the 6MWT in meters $(\mathrm{r}=0.430 \mathrm{p}=0.011)$ and $(\mathrm{r}=0.502$; $\mathrm{p}=0.002$ ), respectively (Figure 1 and 2 ).

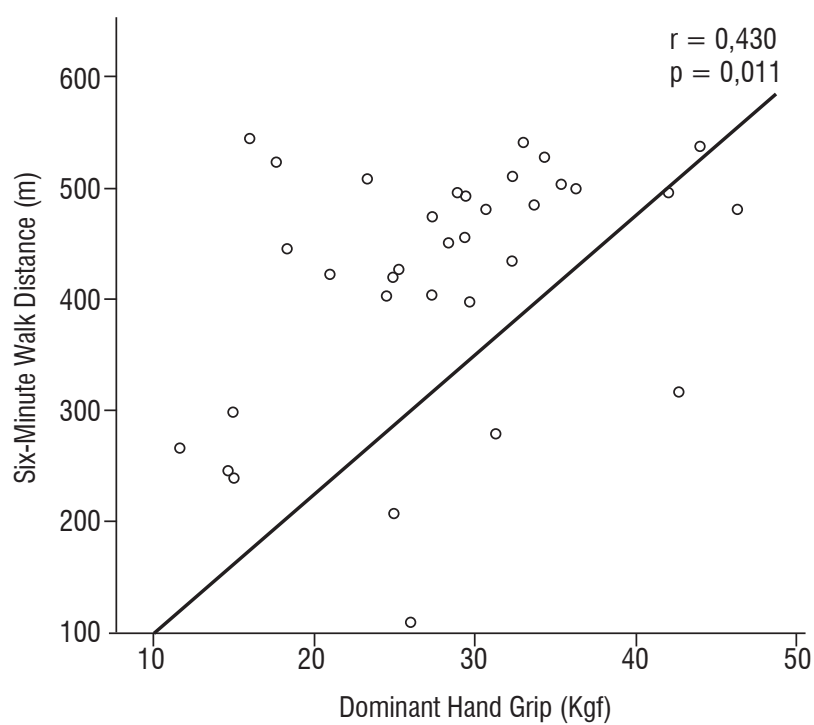

Figure 1 - Correlation between 6MWT (m) and dominant Hand Grip.

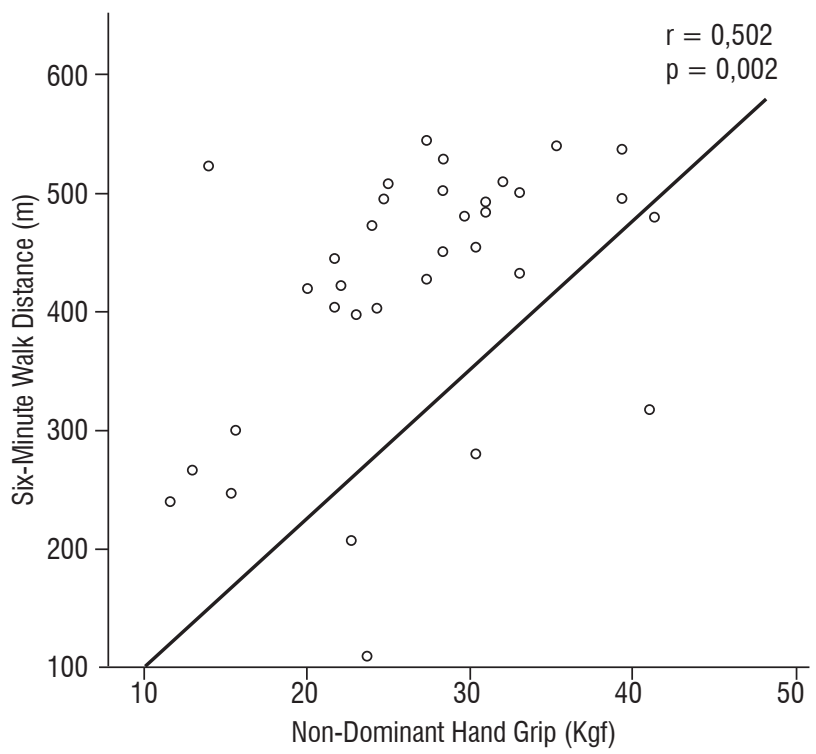

Figure 2 - Correlation between 6MWT (m) and non-dominant Hand Grip.

The HGS also correlated itself significantly and inversely with the BODE Index (Figure 3). It is possible to observe a reduction of HGS related with the worsening of the patients quality of life, which was determined by the quartiles of the BODE index, as described in Table 2, although no significant statistical 
difference was found (values of $\mathrm{p}$ ranging between 0.18 and 0.96 ).

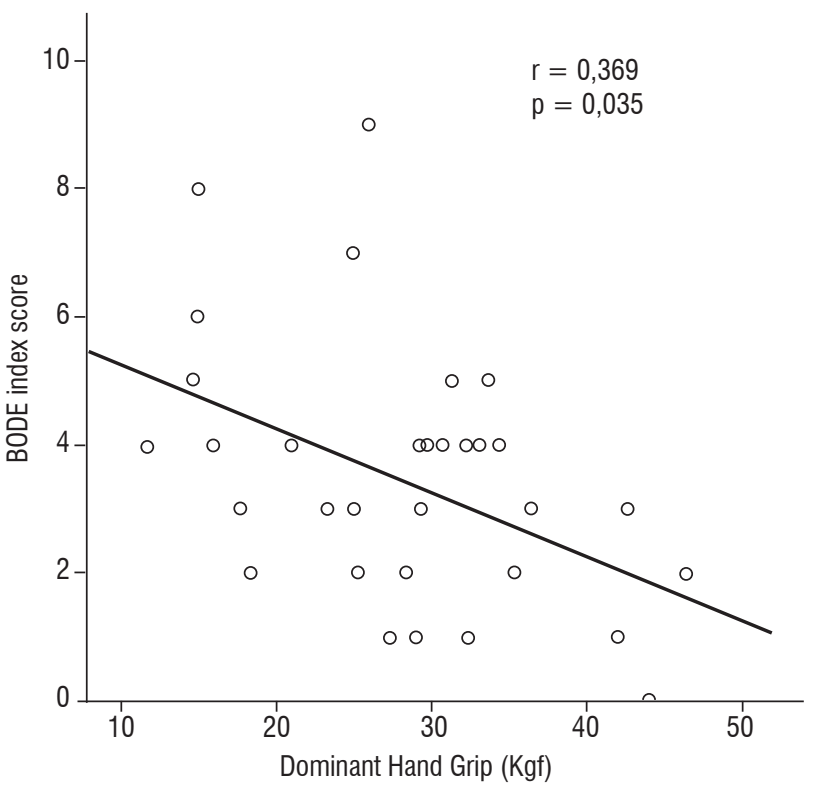

Figure 3 - Correlation between BODE index and Dominant Hand Grip.

Table 2 - BODE index stratified by the Hand Grip dominant and non-dominant in patients with COPD

\begin{tabular}{ccc}
\hline Variables & \multicolumn{2}{c}{ COPD. $(\mathbf{n}=34)$} \\
\hline BODE index & $\begin{array}{c}\text { Dominant } \\
\text { Hand Grip (Kfg) }\end{array}$ & $\begin{array}{c}\text { Non-Dominant } \\
\text { Hand Grip (Kfg) }\end{array}$ \\
Quartile I & $11(33.3 \pm 8.6)$ & $11(29.8 \pm 7.2)$ \\
Quartile II & $15(27.4 \pm 8.3)$ & $15(27.0 \pm 7.7)$ \\
Quartile III & $5(23.9 \pm 8.8)$ & $5(22.9 \pm 7.5)$ \\
Quartile IV & $2(20.5 \pm 7.7)$ & $2(17.6 \pm 8.4)$ \\
\hline
\end{tabular}

Note: Data are presented as mean $\pm \mathrm{SD} ; \mathrm{n}(\%)$ : number sample (frequency); COPD, chronic obstructive pulmonary disease; Índice de BODE: Body Mass-Index: Airflow Obstruction, Dyspnea and Exercise Capacity BODE index: Body Mass-Index. Airflow Obstruction. Dyspnea and Exercise Capacity; Quartile I: 0 to 2 points; Quartile II: 3 to 4 points; Quartile III: 5 to 6 points; Quartile IV: 7 to 10 points.

\section{Discussion}

Our study aimed to analyze the association between hand grip strength and the distance covered in the 6MWT by patients with COPD and we found that the changes that occurred in HGS are directly related with the subject's worsening of survival range in the performance of this test. Our results meet the literature that states that hand grip strength and 6MWT are reduced in patients with COPD particularly in those with hyperinflation (14) and patients with mainly moderate and severe COPD experience a loss of peripheral muscle strength and endurance, exercise capacity and general quality of life (15).

The loss of muscle strength of COPD patients can be related to exercise restrictions which reflect alterations in the respiratory tract, cardiovascular, neuromuscular and neurosensory system in highly variable combinations with multifactorial interactions $(15,16)$. The changes in the peripheral musculature strength and in muscle mass can be associated with a systemic inflammation, reduction of the capillaries in the fibers, and also with the oxidative stress (15, 17), which is more accentuated in the lower limbs.

On the other hand, our results meet the findings of those in the studies, that states that the muscular strength of the upper limbs of COPD patients can be preserved in the distal muscles, due to the fact that they are used in the daily activities, and reduced in the proximal muscles due to increased dyspnea during the activity sustained by the arm $(18,19,20)$. However, studies highlight that there is a very strong correlation between the HGS and the strength of the other peripheral muscles, like the ones evaluated by the strength of the flexors of the elbow and the knee, as well as the respiratory muscle strength (maximal inspiratory muscle pressure and maximum voluntary ventilation) $(15,21)$. In COPD the supply of oxygen to the peripheral and respiratory muscles may be deficient as a result of hypoxemia (22).

The response obtained in the 6MWT reflects the effort made in daily life activities and the short distance covered in this test translates such limitations (21). This is because the intolerance to exercise of these subjects is of multifactorial construction involving more work and oxygen consumption by the respiratory muscles, the dysfunction of the skeletal muscles of the lower limbs and the mechanism of lung dynamic hyperinflation, acting alone or in conjunction (23).

In the same way that the 6MWT influences the BODE index, we found, in our study, a direct association of HGS with the worsening of this index and the consequent worsening of survival of COPD patients. The BODE is considered an index of multidimensional $(24,25)$, classification of the severity of COPD $(26$, 27 ) where a score of 3 points or more is associated 
with an increase of mortality and exacerbation rates in patients with COPD $(28,29,30)$.

Some limitations can be observed in our study, such as the sample size which does not allow us for many inferences and future perspectives, making it possible to evaluate the effectiveness of pulmonary rehabilitation thru improvement of muscle strength and consequently, the performance in the 6MWT.

\section{Conclusion}

The hand grip strength was directly associated with the performance in the Six-Minute Walk Test in our study, where the patients with COPD that presented a lower HGS in the dominant and non-dominant hand also covered less distance and worsening of survival. Further studies are necessary to identify how much the hand grip strength can influence the performance in the 6MWT in this population.

\section{Support and funding}

University of Santa Cruz do Sul-UNISC, DECIT/ SCTIE-MS/FAPERGS/CNPq 1264-2551/13-1 and Hospital Santa Cruz - RS.

\section{References}

1. GOLD - Global Initiative for Chronic Obstructive Lung Disease. Global Strategy for the Diagnoses, Management, and Prevention of Chronic Obstructive Pulmonary Disease (updated 2015).

2. Borel B, Provencher S, Saey D, Maltais, F. Responsiveness of Various Exercise-Testing Protocols to Therapeutic Interventions in COPD. Pulm Med. 2013;2013:410748.

3. Sun KS, Lin MS, Chen YJ, Chen YY, Chen SCC, Chen W. Is asymptomatic peripheral arterial disease associated with walking endurance in patients with COPD? Int J Chron Obstruct Pulmon Dis. 2015;10:1487-92.

4. Pepin V, Saey D, Laviolette L, Maltais F. Exercise capacity in chronic obstructive pulmonary disease: mechanisms of limitation. COPD. 2007;4(3):195-204.
5. Holland AE, Spruit MA, Troosters T, Puhan MA, Pepin V, Saey D, et al. An official European Respiratory Society/ American Thoracic Society technical standard: field walking tests in chronic respiratory disease. Eur Respir J. 2014;44(6):1428-46.

6. Pires SR, Oliveira AC, Parreira VF, Britto RR. Teste de caminhada de seis minutos em diferentes faixas etárias e índices de massa corporal. Rev Bras Fisioter. 2007;11(2):147-51.

7. Rausch-Osthoff AK, Kohler M, Sievi NA, Clarenbach $\mathrm{CF}$, van Gestel AJ. Association between peripheral muscle strength, exercise performance, and physical activity in daily life in patients with Chronic Obstructive Pulmonary Disease. Multidiscip Respir Med. 2014;9(1):37.

8. Martin FG, Nebuloni CC, Najas MS. Correlação entre estado nutricional e força de preensão palmar em idosos. Rev Bras Geriatr Gerontol. 2012;15(3):493-504.

9. Luna-Heredia E, Martín-Peña G, Ruiz-Galiana J. Handgrip dynamometry in healthy adults. Clin Nutr. 2005;24(2):250-8.

10. ATS Committee on Proficiency Standards for Clinical Pulmonary Function Laboratories. ATS statement: guidelines for the six-minute walk test. Am J Respir Crit Care Med. 2002;166(1):111-7.

11. Enright PL. The six-minute walk test. Respir Care. 2003;48(8):783-5.

12. Cuppari L. Guia de Medicina Ambulatorial e Hospitalar: Nutrição Clínica no Adulto. São Paulo: Manole; 2002.

13. Pereira CA, Sato T, Rodrigues CS. New reference values for forced spirometry in white adults in Brazil. J Bras Pneumol. 2007;33(4):397-406.

14. Cortopassi F, Divo M, Pinto-Plata V, Celli B. Resting handgrip force and impaired cardiac function at rest and during exercise in COPD patients. Respir Med. 2011;105(5):748-54.

15. Calik-Kutukcu E, Savci S, Saglam M, Vardar-Yagli N, Inal-Ince D, Arikan H, et al. A comparison of muscle strength and endurance, exercise capacity, fatigue perception and quality of life in patients with chronic obstructive pulmonary disease and healthy subjects: a cross-sectional study. BMC Pulm Med. 2014;14:6. 
16. Rabinovich RA, Vilaró J, Roca J. Evaluation exercise tolerance in COPD patients: the 6-minute walking test. Arch Bronconeumol. 2004;40(2):80-5.

17. Nussbaumer-Ochsner Y, Rabe KF. Systemic manifestations of COPD. Chest. 2011;139(1):165-73.

18. Malaguti C, Napolis LM, Villaça D, Neder JA, Nery LE, Dal Corso S. Relationship between peripheral muscle structure and function in patients with chronic obstructive pulmonary disease with different nutritional status. J Strength Cond Res. 2011;25(7):1795-803.

19. Miranda EF, Malaguti C, Dal Corso S. Peripheral muscle dysfunction in COPD: lower limbs versus upper limbs. J Bras Pneumol. 2011;37(3):380-8.

20. Oliveira MF, Zelt JT, Jones JH, Hirai DM, O’Donnell $\mathrm{DE}$, Verges S, et al. Does impaired 02 delivery during exercise accentuate central and peripheral fatigue in patients with coexistent COPD-CHF? Front Physiol. 2015;5:514.

21. Rantanen T, Volpato S, Ferrucci L, Heikkinen E, Fried LP, Guralnik JM. Handgrip strength and cause-specific and total mortality in older disabled women: exploring the mechanism. J Am Geriatr Soc. 2003;51(5):636-41.

22. Santos DB, Viegas CAA. Correlation of levels of obstruction in COPD with lactate and six-minute walk test. Rev Port Pneumol. 2009;15(1):11-25.

23. Nonato NL, Díaz O, Nascimento AO, Dreyse J, Jardim JR, Lisboa C. Behavior of Quality of Life (SGRQ) in COPD Patients According to BODE Scores. Arch Bronconeumol. 2015;51(7):315-21.

24. Moreira MAF, Medeiros GA, Boeno FP, Sanches PRS, Silva Jr DP, Müller AF. Oxygen desaturation during the six-minute walk test in COPD patients. J Bras Pneumol. 2014;40(3):222-8.
25. Chen X, May B, Di YM, Zhang AL, Lu C, Xue CC, et al. Oral Chinese herbal medicine combined with pharmacotherapy for stable COPD: a systematic review of effect on bode index and six minute walk test. PloS One. 2014;9(3):e91830.

26. Sferrazza Papa GF, Battaglia S, Solidoro P. Novelties in COPD prognosis: evolution of survival indexes. Minerva Med. 2015;106(2 Suppl 2):9-16.

27. Silva JRG, Vasconcelos TB, Macena RHM, Bastos VPD, Morano MTAP, Rocha EMM, et al. Análise do índice BODE em pacientes com DPOC severa submetidos a um programa de reabilitação pulmonar. J Health Biol Sci. 2013;1(3):108-15.

28. Martin JM, Carrizo SJ, Casanova C, Martinez-Camblor P, Soriano JB, Agusti AG, et al. Prediction of risk of COPD exacerbations by the BODE index. Respir Med. 2009;103(3):373-8.

29. Dreyse J, Díaz O, Repetto PB, Morales A, Saldías F, Lisboa C. Do frequent moderate exacerbations contribute to progression of chronic obstructive pulmonary disease in patients who are ex-smokers? Int J Chron Obstruct Pulmon Dis. 2015;10:525-33.

30. Mantoani LC, Hernandes NA, Guimarães MM, Vitorasso RL, Probst VS, Pitta F. Does the BODE index reflect the level of physical activity in daily life in patients with COPD? Rev Bras Fisioter. 2011;15(2):131-7.

Received in 12/03/2015

Recebido em 03/12/2015

Approved in 10/25/2016

Aprovado em 25/10/2016 